\title{
The Podlaskie White Stork Trail - ecotourism on the Podlaskie area
}

\author{
Rafał Moroń, Aleksandra Vierek ${ }^{1, *}$ \\ ${ }^{1}$ The Jerzy Kukuczka Academy of Physical Education in Katowice, \\ 72A Mikołowska St., Katowice, Poland \\ *E-mail address: a.vierek@awf.katowice.pl
}

\begin{abstract}
In this paper tourist sight and ecotouristic values of Podlaskie area and brand tourist product "The Podlaskie White Stork Trail", was presented. This bicycling touristic route including the regions four National Parks (The Białowieża, Biebrza, Narew and Wigry NPs) and the Suwałki Landscape Park. The pristine of nature, rich culture and history of this land are ecotouristic attractions. Ecoturism is a form of active tourism involving visiting relatively undisturbed, often protected natural areas as: national or landscape parks and sanctuaries. This is tourism to areas of highly cultural and historical values, too.
\end{abstract}

Keywords: ecotourism, birdwatching, National Park, Podlaskie White Stork Trail, north-eastern Poland

\section{Na Bocianim Szlaku - ekoturystyka na Podlasiu}

\section{STRESZCZENIE}

W pracy zaprezentowano (eko)turystyczne atrakcje jakie oferuje Podlasie wraz z markowym produktem turystycznym „Podlaskim Szlakiem Bocianim”. Ten najdłuższy na Podlasiu rowerowy szlak łączy cztery parki narodowe polski północno-wschodniej (Białowieski, Biebrzański, Narwiański i Wigierski) oraz Suwalski Park Krajobrazowy. Nieskażona przyroda, bogata kultura i historia tych ziem pozwalają na uprawianie tu szeroko pojętej ekoturystyki. Jest to stosunkowo młoda forma turystyki aktywnej polegająca na odwiedzaniu obszarów relatywnie nienaruszonych, często chronionych, takich jak parki narodowe, krajobrazowe czy rezerwaty przyrody, ale także o wysokich i unikatowych walorach kulturowych i historycznych.

Stowa kluczowe: ekoturystyka; turystyka ornitologiczna; Park Narodowy; Podlaski Szlak Bociani; Polska północno-wschodnia 


\section{WSTĘP}

Tym, co w dużym stopniu wpływa na turystyczną atrakcyjność danego regionu jest obecność na jego terenie różnorodnych form ochrony przyrody, zwłaszcza parków narodowych czy krajobrazowych. Na Podlasiu wydzielono cztery parki narodowe oraz trzy parki krajobrazowe. Jak na stosunkowo niewielki obszar ich ilość jest zdumiewająca. To tu znajdują się najstarszy park narodowy i krajobrazowy w Polsce - odpowiednio Białowieski PN i Suwalski PK. Biebrzański PN jest największym powierzchniowo parkiem narodowym w kraju, a anastomozujący charakter Narwi w obrębie Narwiańskiego PN jest ewenementem w skali światowej.

Walory przyrodnicze parków narodowych północno-wschodniej Polski zostały docenione również na arenie międzynarodowej, czego efektem jest objęcie tych obszarów ochroną międzynarodową. Tereny te należą do europejskiej sieci obszarów NATURA 2000. Parki Narodowe: Biebrzański, Narwiański i Wigierski wpisane zostały na listę obszarów wodno-błotnych chronionych konwencją z Ramsar z roku 1971. Puszcza Białowieska jest jedynym całkowicie naturalnym miejscem w Polsce, które figuruje na Liście Światowego Dziedzictwa UNESCO. Oprócz tego, obszar Białowieskiego PN wpisany jest na listę światowych rezerwatów biosfery UNESCO.

Cała powierzchnia woj. podlaskiego wchodzi w obszar tzw. „Zielonych Płuc Polski”, charakteryzujących się olbrzymim potencjałem dotyczącym szeroko pojętego ekorozwoju. Niezwykłe walory przyrodnicze w połączeniu z różnorodnością kulturową mieszkańców, stanowią atrakcyjny turystycznie teren. Podlasie jest najmniej przekształconym przez człowieka regionem kraju. Dobrze zachowane i bogate dziedzictwo kulturowe, w połączeniu $\mathrm{z}$ najniższym $\mathrm{w}$ kraju poziomem zurbanizowania obszaru ${ }^{1}-60$ osób na $\mathrm{km}^{2}-$ stwarza doskonałe warunki pod uprawę turystyki kulturowej czy ekoturystyki. Ekoturystyka, jako forma turystyki przyjazna środowisku i nie ingerująca w ekosystemy, w dobie idei zrównoważonego rozwoju coraz bardziej zyskuje na znaczeniu. To właśnie na Podlasiu turyści znajdą spokój, piękne krajobrazy oraz przyrodę w niewielkim stopniu przekształconą ręką człowieka. Wytyczono tu setki kilometrów tras pieszych i rowerowych $-\mathrm{z}$ flagowym „Podlaskim Szlakiem Bocianim” - łączącym wszystkie parki narodowe tej części kraju. Zakazy prawne obowiązujące w parkach narodowych niejako „zmuszają” turystów do uprawy ekoturystyki.

\section{TURYSTYKA ZRÓWNOWAŻONA A EKOTURYSTYKA}

Pojęcie turystyki zrównoważonej (rozpowszechnione po Szczycie Ziemi w Rio de Janeiro w 1992 roku) jest pojęciem znacznie szerszym od wąskiego rozumienia ekoturystyki. Turystyką zrównoważoną nazwać można każdy rodzaj turystyki: w miastach i na obszarach wiejskich, uwzględniający dbałość o środowisko przyrodnicze i jego zasoby. Zatem mianem turystyki zrównoważonej określić można $\mathrm{np}$. turystykę biznesową realizowaną $\mathrm{w}$ miejscach atrakcyjnych przyrodniczo, w niewielkich ośrodkach, stosujących się do zasad ekologicznego zarządzania dobrami (Zaręba, 2006).

Ekoturystyka jest najczystszą $\mathrm{z}$ form turystyki zrównoważonej. Miejscem jej uprawiania są naturalne ekosystemy, środowiska niezmienionej przyrody, często obszary chronione oraz miejsca ciekawych, zanikających i odmiennych kultur. Ekoturystami są ludzie

\footnotetext{
${ }^{1}$ http://www.stat.gov.pl/, data wejścia [10.06.2014 r.]
} 
„o dużej wrażliwości i świadomości ekologicznej, okazujący respekt i szacunek naturze, zainteresowani zjawiskami przyrodniczymi i kulturowymi” (Zaręba, 2006, s. 53).

Wśród najważniejszych cech ekoturystyki wymienia się ochronę ekosystemów przyrodniczych i odrębności lokalnych kultur. Ekoturystyka jest formą turystyki aktywnej, w której rolą turysty, jest świadome podróżowanie w miejsca atrakcyjne przyrodniczo i kulturowo. Poprzez dostarczanie środków finansowych w wyniku ruchu turystycznego ekoturystyka wpływa na ochronę dziedzictwa przyrodniczego i kulturowego, podnosi poziom ekonomiczny lokalnych społeczności (Zaręba, 2006). Ważnym celem ekoturystyki jest szeroko pojęta edukacja ekologiczna różnych grup wiekowych, społecznych i zawodowych. Zielona turystyka - jak często nazywa się ekoturystykę - jest pożądaną formą podróżowania po obszarach prawnie chronionych. Poprzez ekologiczne podróżowanie, turyści przyczyniają się do skuteczniej ochrony przyrody w parkach narodowych, krajobrazowych i rezerwatach przyrody. Korzyści są obopólne: obszary chronione otrzymują korzyści ekonomiczne i, w związku z proekologiczną świadomością turystów, ochronę zasobów świata przyrodniczego i kulturowego, natomiast ekoturyści dostają w zamian czyste, naturalne środowisko, cisze, spokój oraz możliwość poznania innych kultur i uczestniczenia w nieznanych obrzędach czy świętach. Korzystnym faktem jest również zwiększanie świadomości lokalnych mieszkańców, którzy widząc zainteresowanie ich najbliższym otoczeniem, mogą aktywnie uczestniczyć $w$ jego ochronie i promocji. Z racji tego, istotna jest edukacja społeczna i ekologiczna społeczności, zamieszkującej obszary chronione lub je otaczające (Zaręba, 2006).

\section{ETNOGRAFIA PODLASIA}

Podlasie jest najbardziej zróżnicowanym kulturowo regionem kraju. Występują tu takie mniejszości narodowe jak: Litwini, Ukraińcy, Rosjanie, Białorusini, Romowie, Żydzi czy Tatarzy. Najliczniej reprezentowaną mniejszością jest mniejszość białoruska. Pod względem wyznaniowym spotyka się tu wyznawców rzymskokatolickich, prawosławnych czy islamskich. We wschodniej części Podlasia dominuje wyznanie prawosławne. Zachodni obszar w głównej mierze zamieszkują katolicy (Barwiński, 2004; Durydiwka i Kociszewski, 2013).

O kulturowym bogactwie obszaru decydowała jego burzliwa historia. Obecnie Podlasie znajduje się na terytorium Polski. W przeszłości bywało inaczej, należąc do terytorium innych państw, m.in. Rusi, Litwy, Rzeczpospolitej Obojga Narodów czy w czasie zaborów do Prus, często będąc obszarem granicznym i strategicznie ważnym. Świadczy o tym budowa twierdzy w Osowcu, której celem było zatrzymanie wroga jak najbliżej granic państwa. Wpływ na mieszankę kulturową spotykaną obecnie, miał zmieniający się przebieg granicy pomiędzy Polską a Związkiem Radzieckim, który spowodował przyłączenie ziem zamieszkiwanych przez Białorusinów i Ukraińców do Polski (Durydiwka i Kociszewski, 2013).

Gwarą dominującą jest tzw. gwara białostocka, wywodząca się z szerszego zjawiska dialektu północnokresowego. Genezą gwary białostockiej - żartobliwie nazywanej śledzikowaniem - jest wpływ języka białoruskiego i litewskiego (w mniejszym stopniu także języka rosyjskiego, ukraińskiego i jidysz), a jej powstanie wiąże się z Unią Lubelską. Mieszkańcy północno-wschodniej Polski dźwięcznie ,zaciągają”, co w istocie oznacza, iż akcentowana samogłoska jest dłużej wymawiana ${ }^{2}$.

\footnotetext{
${ }^{2}$ http://www.bialystok.pl/, data wejścia [15.11.2013 r.]
} 
Także lokalna kuchnia jest jednym $\mathrm{z}$ elementów wchodzących w skład szerzej pojmowanej kultury. Podlasie reprezentowane jest na „Liście Produktów Tradycyjnych” przez 50 produktów, m.in. ser podlaski, kumpiak podlaski, sejneński szczupak faszerowany, kruszewski ogórek herbowy, makowiec z Ejszeryszek, miód augustowski, bliny po litewsku, podlaską samogonkę zbożową ${ }^{3}$. Pierekaczewnik jest jedynym jak dotychczas produktem oznaczonym unijną ochroną - „Gwarantowana Tradycyjna Specjalność” ${ }^{4}$. Koronnym zaś produktem Podlasia jest sękacz - rodzaj wypieku z ciasta piaskowego, wywodzący się z tradycji jaćwieskich. Tradycyjne tatarskie potrawy skosztować można we wsi Kruszyniany.

Różnorodność kulturowa powoduje, iż na obszarze badanego regionu występuje wiele zabytków architektonicznych związanych z danym narodem i wyznaniem (synagogi, meczety czy cerkwie). Liczne są charakterystyczne dla danej mniejszości obrzędy oraz lokalne święta, które są doskonałą okazją do integracji z innymi kulturami. Nic nie zastąpi jednak ludzi zamieszkujących owe tereny, którzy, mimo, iż różni, potrafią egzystować z wzajemnym szacunkiem zarówno dla siebie, jak i dla odwiedzających ich gości.

\section{PODLASKI SZLAK BOCIANI}

Podlaski Szlak Bociani jest koronnym produktem turystycznym Podlasia. To rowerowy szlak, powstały w 2002 roku z inicjatywy Północnopodlaskiego Towarzystwa Ochrony Ptaków (PTOP) oraz EKOTON sp. z o. o. i wsparciu m.in. Ministerstwa Gospodarki oraz Samorządu Województwa Podlaskiego. Od 2003 roku szlak posiada certyfikat produktu turystycznego Polskiej Organizacji Turystycznej. Obecna długość szlaku - tj. 412,5 km obowiązuje od roku 2006, kiedy oznakowano jego suwalską część. Trasa zaczyna się w Białowieży i kończy w Stańczykach (Ryc. 1) - miejscowości uznawanej za bocianią stolicę Polski ${ }^{5}$.

Podlaski Szlak Bociani należy do europejskiej sieci zielonych szlaków „greenways”, które skierowane są do turystów niezmotoryzowanych w celu ochrony środowiska naturalnego oraz podnoszenia jakości życia na terenach, przez które przebiegają. Podstawową funkcją szlaków ,greenways” jest transport zrównoważony i bezpieczeństwo oraz promocja zdrowego stylu życia. Zielone szlaki wspomagają rozwój ekoturystyki, chronią dziedzictwo przyrodnicze i kulturowe oraz wspierają ekonomiczno-społeczny rozwój lokalnej przedsiębiorczości ${ }^{6}$.

\section{1. Przyrodnicze i kulturowe walory oraz infrastruktura turystyczna Podlaskiego Szlaku Bocianiego}

Poniżej opisano najważniejsze walory turystyczne Podlaskiego Szlaku Bocianiego z uwzględnieniem obszarów chronionych oraz miejsc cennych pod względem kulturowym. W opisie uwzględniono infrastrukturę ułatwiającą penetrowanie i podziwianie środowiska naturalnego oraz imprezy lokalne pozwalające na poznanie walorów etnograficznych wielu miejsc.

Białowieski PN niemal w całości swojego obszaru jest zalesionym fragmentem Puszczy Białowieskiej. Niski poziom zaludnienia wpływa na „dziewiczość” tego miejsca.

\footnotetext{
${ }^{3}$ http://www.minrol.gov.pl/, data wejścia [29.08.2014 r.]

${ }^{4}$ http://www.wrotapodlasia.pl/, data wejścia [16.11.2013 r.]

${ }^{5}$ http://www.podlaskiszlakbociani.pl/, data wejścia [01.10.2014 r.]

${ }^{6}$ http://www.greenways.pl/pl/, data wejścia [29.08.2014 r.]
} 


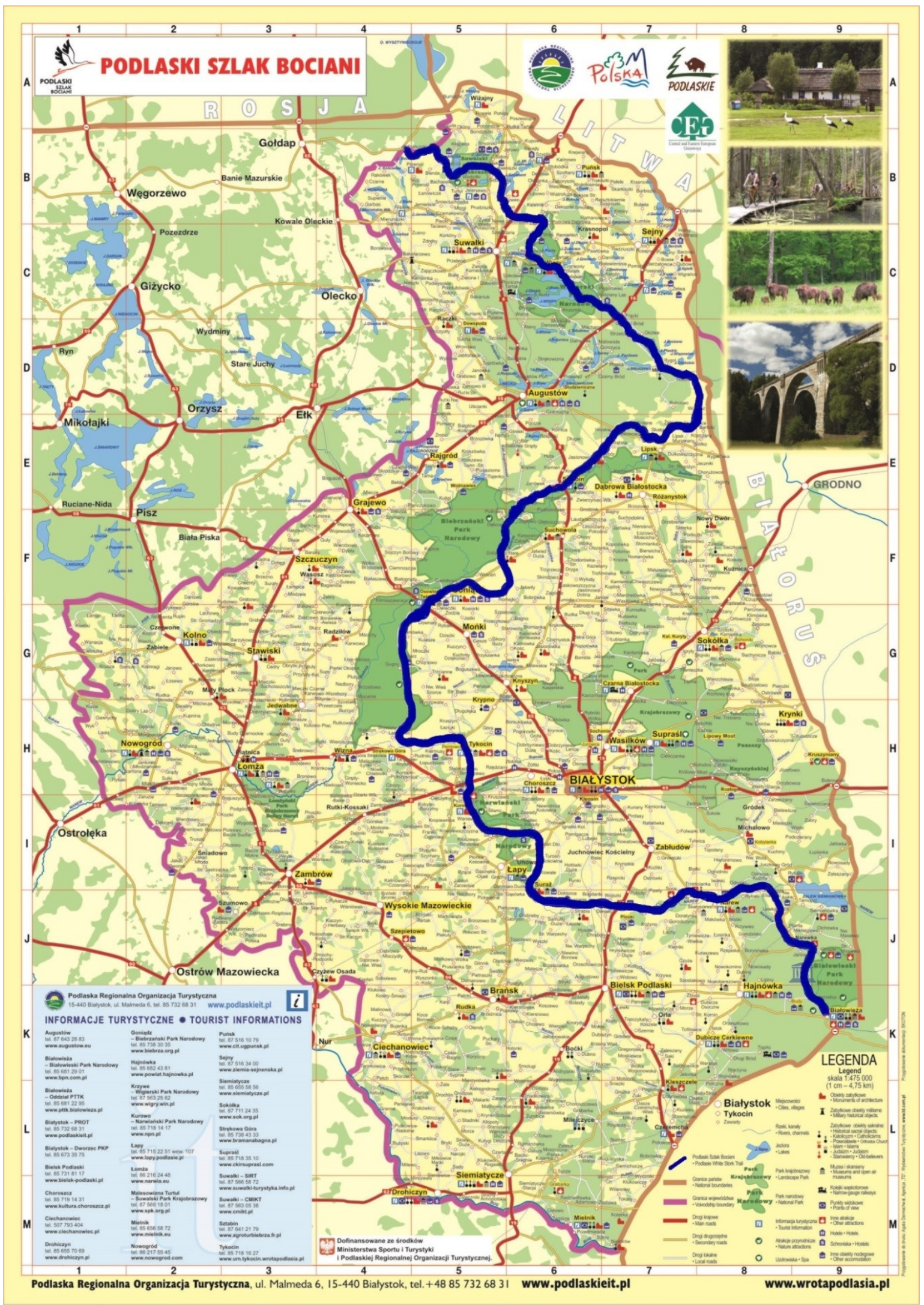

Ryc. 1. Przebieg Podlaskiego Szlaku Bocianiego (Źródło: opracowanie własne na podst. www.podlaskiszlakbociani.pl). 


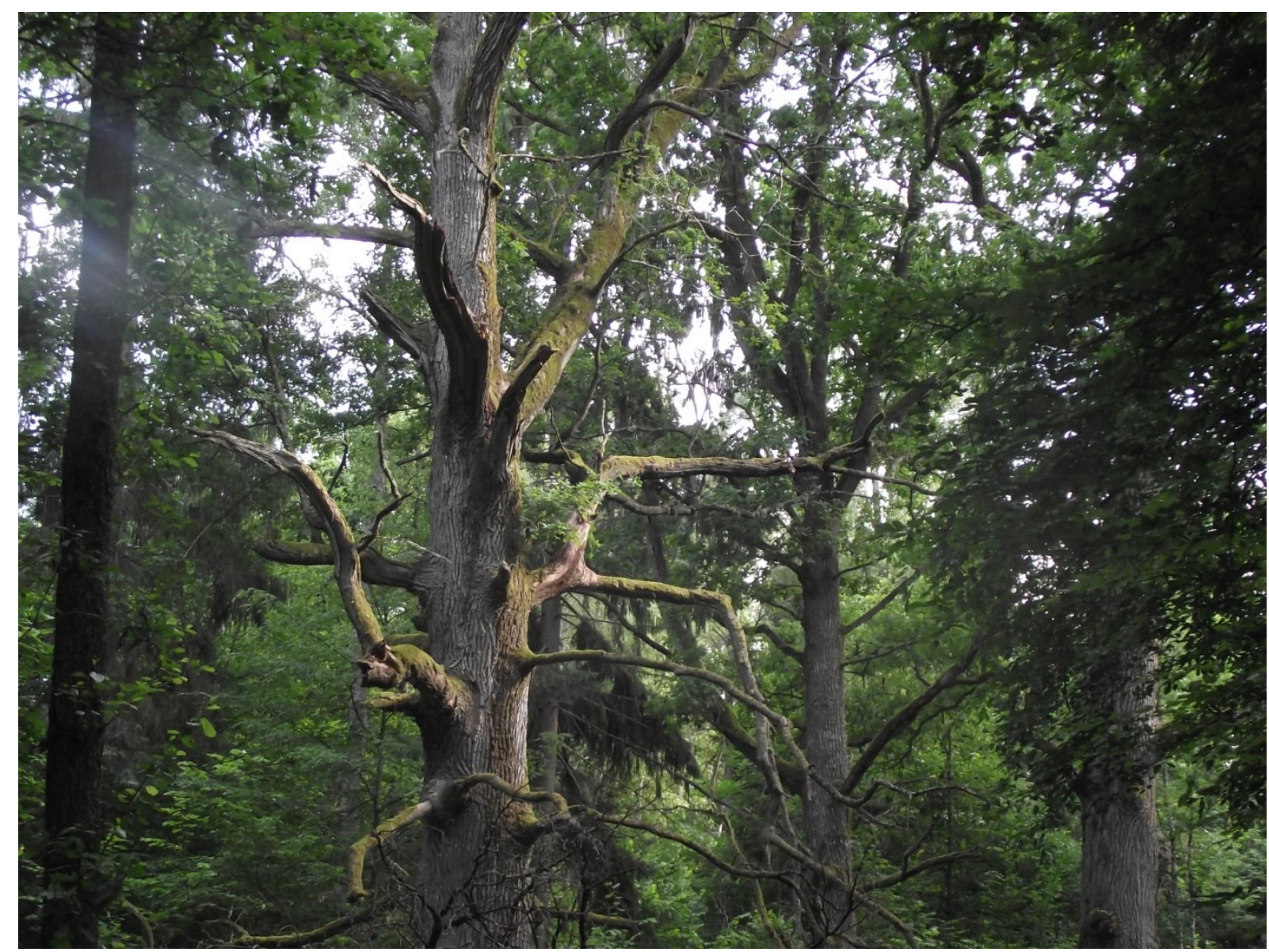

Fot. 1. Jeden z dębów na trasie ścieżki „Dęby Królewskie” (Fot. Rafał Moroń).

Największą atrakcją parku jest Puszcza - najlepiej zachowany fragment lasu pierwotnego na niżu europejskim. Szczególnie cenna jest jej różnorodność. Najczęstszym typem lasu jest, występujący na żyznych glebach, grąd. Kolejne są bory świerkowe (fragment borealnego stanowiska tajgi syberyjskiej) i olsy. W większości są to lasy pierwotne - nie posadzone przez człowieka - dzięki czemu są bardziej odporne na choroby i szkodniki. Najcenniejszym przyrodniczo i naukowo fragmentem Puszczy jest obszar ochrony ścisłej parku narodowego. Symbolem Puszczy jest żubr - największy europejski ssak. Puszcza Białowieska uznawana jest za światową rezerwę reprodukcyjną tego gatunku - wszystkie obecnie żyjące żubry pochodzą z hodowli białowieskiej (Wysmułek, 1994). Najokazalszymi z drzew Puszczy są rozłożyste dęby. Na liczącej kilkaset metrów ścieżce dydaktycznej „Dęby Królewskie", zobaczyć można kilkanaście wiekowych okazów, noszących imiona dawnych polskich władców ${ }^{7}$ (Fot. 1). Interesującym walorem parku jest oddalone kilka kilometrów od Białowieży „miejsce mocy” - pradawne miejsce kultu Słowian, któremu przypisuje się magiczne właściwości. Potwierdziły to badania, które wykazały na tym obszarze obfitość podziemnych cieków wodnych i rzek. Efektem korzystnego działania sił przyrody jest prawdopodobnie bujna roślinność. Niektóre z drzew wyrastają z jednego pnia i dzielą się na kilka konarów. Pozostałością po dawnych pogańskich kultach są, będące elementem tegoż,

${ }^{7}$ http://www.bpn.com.pl/, data wejścia [01.0.2014 r.] 
kamienie $^{8}$. Zwierzęta $\mathrm{w}$ warunkach półnaturalnych podziwiać można w Rezerwacie Pokazowym Żubrów. Wśród eksponowanych znajdują się m.in.: żubr, żubroń, wilk, ryś, konik polski czy jeleń.

Muzeum Przyrodniczo-Leśne w siedzibie parku jest najstarszym muzeum z polskich parków narodowych. Prezentuje charakterystyczne dla Puszczy zbiorowiska leśne, procesy ekologiczne, zjawiska przyrodnicze oraz historię kultury9 .

Białowieski PN to nie tylko bogactwo przyrody, ale również obszar atrakcyjny kulturowo. Nieopodal siedziby parku znajduje się prawosławna cerkiew pod wezwaniem św. Mikołaja Cudotwórcy (Fot. 2). Świątynia zbudowana została z czerwonej cegły u schyłku XIX wieku na planie krzyża greckiego ${ }^{10}$.

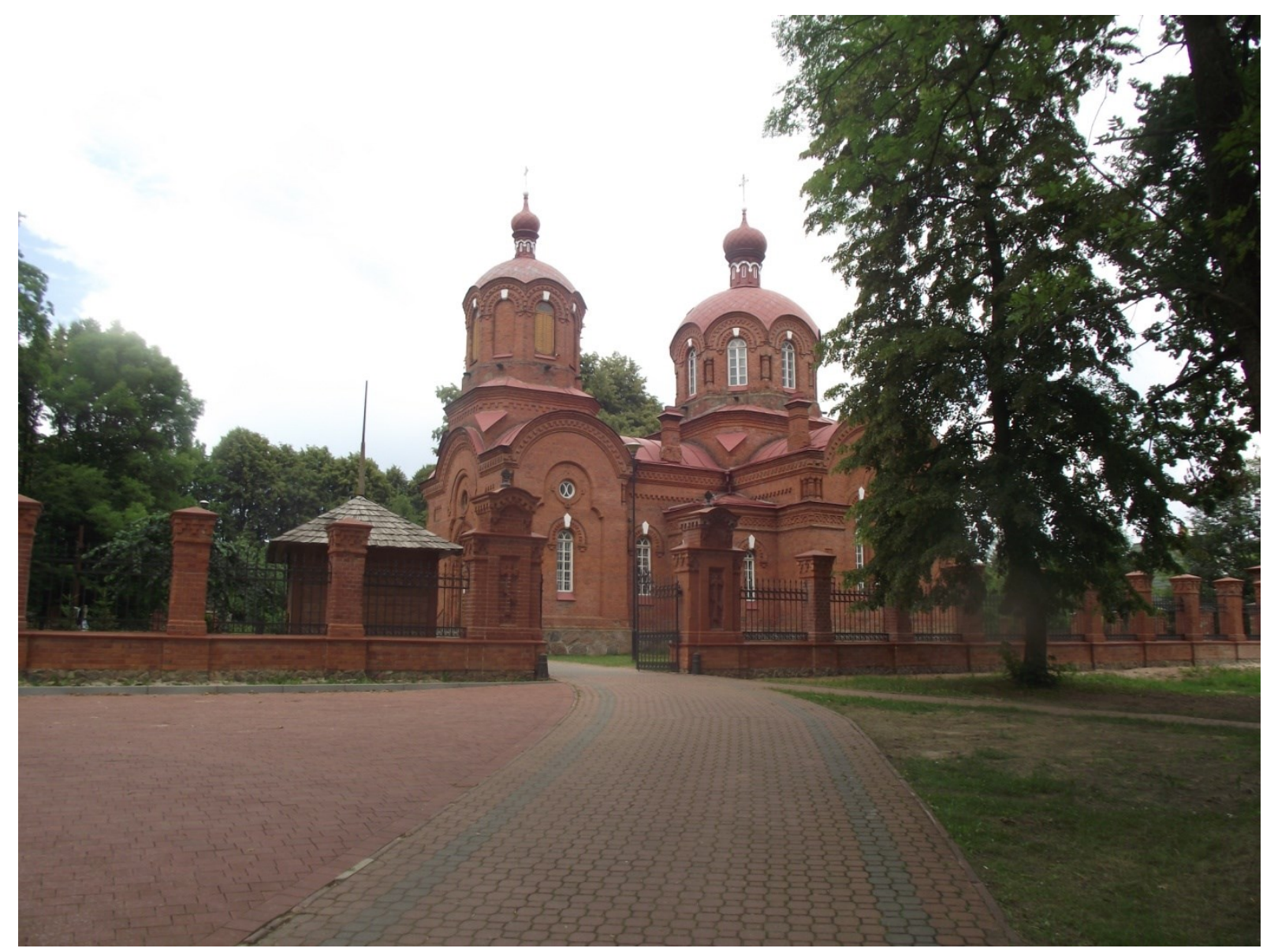

Fot. 2. Cerkiew pw. Św. Mikołaja Cudotwórcy w Białowieży (Fot. Rafał Moroń).

Dyrekcja Białowieskiego PN urzęduje w sąsiedztwie Parku Pałacowego, który - w stylu angielskim, z luźnymi kompozycjami opartymi głównie na wątku roślinnym - zaprojektował Walerian Kronenberg. Głównym budynkiem parku był niegdyś pałac, jednak spłonął w czasie II wojny światowej. Zachowały się natomiast inne budynki, m.in.: Dom Marszałkowski, Dom Jegierski, Dom Zarządu, Dom Szoferów oraz najstarszy białowieski budynek - drewniany

\footnotetext{
${ }^{8}$ http://www.bialowieza-info.eu/, data wejścia [07.05.2014 r.]

${ }^{9}$ http://bpn.com.pl/, data wejścia [08.05.2014 r.]

${ }^{10}$ http://www.ciekawepodlasie.pl/, data wejścia [01.10.2014 r.]
} 
dworek z 1845 roku. Najstarszy zabytek parku znajduje się na grobli dzielącej dwa stawy. Jest to obelisk upamiętniający królewskie polowanie z 1752 r., któremu przewodniczył August III Sas ${ }^{11}$.

Od 2009 roku w Białowieży organizowany jest festyn pt. „Polowanie Króla Jagiełły”, na którym można cofnąć się w czasie oglądając m.in.: turniej rycerski czy łuczniczy, a także zobaczyć i zdegustować potrawy kuchni średniowiecznej ${ }^{12}$. W pierwszą sobotę lipca odbywa się impreza pod nazwą „Kupalle”, w Polsce znana jako Noc Świętojańska. Nazwa i charakter imprezy to ukłon w stronę mniejszości białoruskiej. Impreza zaczyna się pochodem spod dawnego dworca w Białowieży, kończy zaś w amfiteatrze, gdzie występują polskie i białoruskie zespoły ludowe ${ }^{13}$.

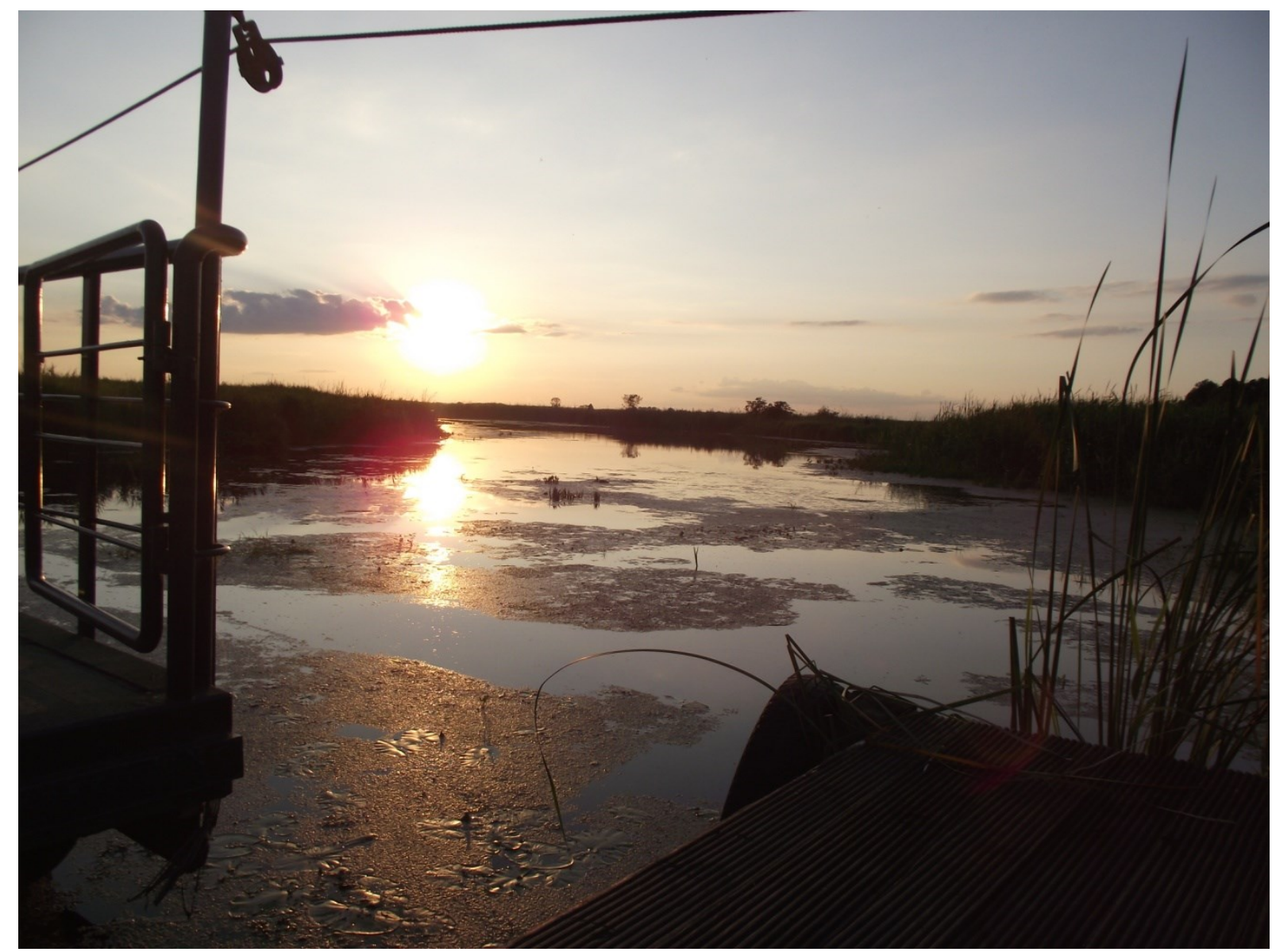

Fot. 3. „Serce” Doliny Narwi na trasie kładki Śliwno-Waniewo (Fot. Rafał Moroń).

Głównym walorem przyrodniczym Narwiańskiego Parku Narodowego jest ok. 50kilometrowej długości fragment Narwi - od Rzędzian do Surażu - charakteryzujący się nietypowym, anastomozującym systemem rzecznym. Oryginalny, tzw. warkoczowy, charakter rzeka zawdzięcza procesowi awulsji, czyli dzielenia się koryt i powstawania nowych (w skutek zatorów lodowych czy roślinnych lub różnicy w wysokości lustra wody

\footnotetext{
${ }^{11}$ http://www.bpn.com.pl/, data wejścia [06.01.2014 r.]

${ }^{12}$ http://www.bialowieza.pl/, data wejścia [06.01.2014 r.]

${ }^{13}$ http://www.bialystokonline.pl/, data wejścia [06.01.2014 r.]
} 
poszczególnych koryt; Gradziński, 2004). Dolina rzeki tworzy obszar bogaty zarówno florystycznie, jak i faunistycznie. Na polach licznie spotykane jest ptactwo, wśród którego prym wiodą bociany i żurawie. Wokół dominuje wiejski krajobraz, a na większości skrzyżowań znajdują się kapliczki lub krzyże. Najdogodniejszym miejscem na obserwację osobliwego charakteru rzeki jest kładka Śliwno-Waniewo, która wnika w sam środek doliny rzeki (Fot. 3). Podróż drewnianą ścieżką możliwa jest dzięki kilku pontonowym, ręcznie napędzanych przeprawach przez rzeczne koryta. We wsi Bokiny w okolicach kościoła, znajduje się doskonały punkt widokowy na dolinę Narwi.

Na uwagę zasługuje siedziba Dyrekcji Narwiańskiego PN, znajdująca się w XIXwiecznym dworku. Posiadłość otacza park z kilkunastoma drzewami objętymi ochroną w postaci pomników przyrody ${ }^{14}$.

Ciekawym kulturalnym wydarzeniem regionu jest Ogólnopolski Dzień Ogórka. Impreza odbywa się w Kruszewie, a na uczestników czeka nie tylko degustacja ogórka, ale również rozmaite konkursy. W Kurowie, zazwyczaj pod koniec sierpnia, ma miejsce Biesiada Miodowa, podczas której można spróbować i zaopatrzyć się w ekologiczny miód (spadziowy, rzepakowy czy lipowy), a także wyroby z niego, takie jak nalewka miodowa lub świece woskowe ${ }^{15}$.

Prawdziwą kulturową perełką regionu jest Suraż - najmniejsze polskie miasto. Obecny układ przestrzenny miasta nie zmienił się przez stulecia. Pieczę nad miastem „trzyma” niegdysiejsze grodzisko, usytuowane na wzniesieniu, tzw. „Góra Królowej Bony”. Niezwykle interesującym miejscem jest Prywatne Muzeum Archeologiczno-Etnograficzne Władysława Litwińczuka. Wśród eksponatów znajdują się.: przedwojenne numizmaty, żydowskie obligacje, szable, kule obronne, mundury wojenne, prymitywne narzędzia czy przedwojenne radia $\mathrm{i}$ telefony ${ }^{16}$. W mieście odbywa się coroczny festiwal pt. „Grodzisko” - prezentujący elementy średniowiecznego życia (Największe atrakcje...).

Największy powierzchniowo polski park narodowy - Biebrzański - charakteryzują niezmierzone połacie bagiennego krajobrazu. To jedno z niewielu miejsc w Polsce, gdzie odległości pomiędzy sąsiednimi osadami liczone są w kilometrach. Znajdujące się $\mathrm{w}$ południowym basenie Biebrzy Bagno Podlaskie oraz Bagno Lawki, to największe w Polsce obszary torfowisk niskich. Środkowy basen z rezerwatami „Grzędy” oraz „Czerwone Bagno”, to niegdysiejsza jedyna w kraju ostoja łosia (II wojnę światową przetrwało jedynie kilkanaście sztuk tych zwierząt; Kalicka, 2009). Dogodnym miejscem do zapoznania się z charakterem południowego basenu Biebrzy jest podróż dziurawą jak szwajcarski ser „carską drogą", która w tym miejscu jest fragmentem Podlaskiego Szlaku Bocianiego. Otoczeniem drogi są otwarte połacie bagiennego krajobrazu oraz bory sosnowo-świerkowe i olsy. Wśród lasu okalającego szosę, najatrakcyjniejszy jest bór świerkowy i podmokły ols. Częstym gościem „carskiej drogi” jest łoś (Fot. 4), którego nie trzeba szukać daleko pośród mokradeł. „Carska droga" to także początek wszystkich ścieżek przyrodniczych południowej części parku, którymi są: „Grobla Honczarowska”, „Barwik”, „Długa Luka” i „Wokół Fortu IV Twierdzy Osowiec”" "Szczególnie interesująca jest ścieżka „Barwik”. 10 - kilometrowa trasa wiodąca przez Bagno Podlaskie, w pełni ukazuje jego charakter - bagienne turzycowiska, zakrzaczenia czy grądy i młode grądziki. Trasa nie jest łatwa, a czasem niedostępna z uwagi na podmokły teren. Łatwiejszą i równie interesującą ścieżką jest „Grobla Honczarowska”.

\footnotetext{
${ }^{14}$ http://www.npn.pl/, data wejścia [10.01.2014 r.]

${ }^{15}$ http://www.atrakcjepodlasia.pl/, data wejścia [18.12.2013 r.]

${ }^{16}$ http://dziedzictwo.ekai.pl/, data wejścia [10.01.2014 r.]

${ }^{17}$ http://www.biebrza.org.pl/, data wejścia [26.04.2014 r.]
} 


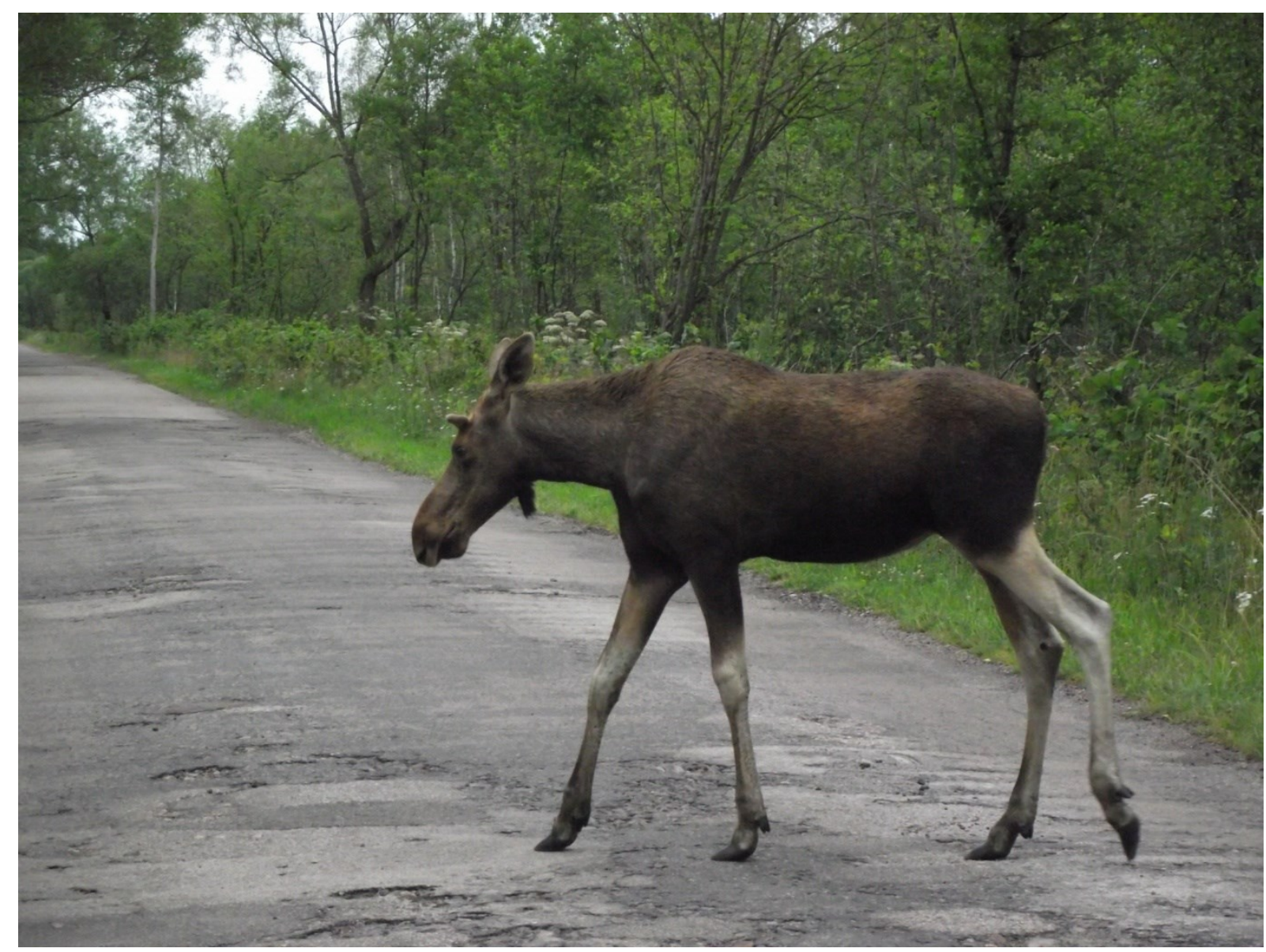

Fot. 4. Łoś na „carskiej drodze” (Fot. Rafał Moroń).

Trasa długości około $3,5 \mathrm{~km}$ jest $\mathrm{w}$ pełni sucha i dostępna. $\mathrm{Z}$ wieży widokowej podziwiać można największe w Polsce kompleksy torfowisk niskich (Biebrzańskie szlaki..., 2006).

Najdogodniejszym punktem widokowym na obserwację bagiennego krajobrazu południowej doliny Biebrzy jest wieża obserwacyjna w okolicach Gugien, na trasie ścieżki „Barwik”. Trudno się tu dostać - nie ma ubitej trasy, trzeba przedzierać się przez teren podmokły, jednak warto podjąć trud takiej wędrówki. Stąd rozciąga się widok na horyzont torfowisk niskich bagien biebrzańskich (Fot. 5). Na obszarze środkowego basenu Biebrzy wytyczono dwa rezerwaty: „Grzędy” i „Czerwone Bagno”. Turystycznie udostępniony jest tylko rezerwat „Grzędy”. Grzędy są lokalnym określeniem piaszczystych wzniesień, wystających ponad bagienne otoczenie, na których osiedlali się ludzie. Najczęstszym typem siedlisk na terenie rezerwatu „Grzędy” są suche bory sosnowe, bory bagienne, olsy i torfowiska. W niektórych rejonach doświadcza się rzadkiego widoku lasu grądowego na piaszczystym podłożu. Spośród zwierząt obserwować tu można nazywanego „królem bagien” łosia oraz borsuka, lisa, sarnę czy, przy odrobinie szczęścia, wilka, rysia i orła przedniego. Czerwone Bagno objęto ochroną w latach 20-tych XX wieku w celu utrzymania populacji łosia. Zwierzęta te, jedynie tutaj - w liczbie kilkunastu sztuk - przetrwały światowe wojny. Obecnie obszar ten jest najliczniejszą ostoją tego zwierzęcia w kraju: około 600 sztuk. Ostoję mają tutaj również: wilk, orlik grubodzioby i krzykliwy, bielik, puchacz i dzięcioł białogrzbiety. Najczęstszym typem lasu jest bór bagienny. 


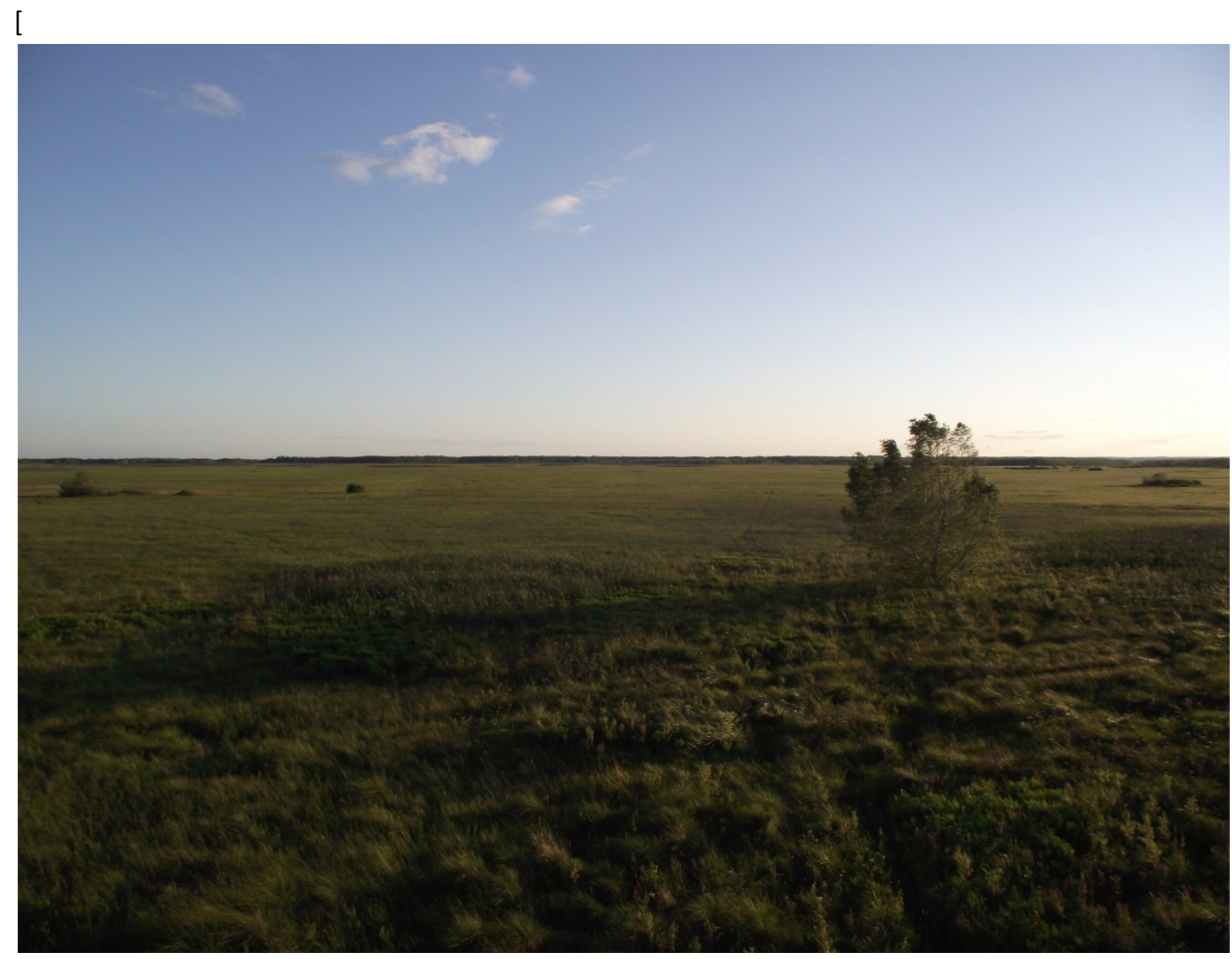

Fot. 5. Bagno Podlaskie - widok z wieży obserwacyjnej w okolicach Gugien (Fot. Rafał Moroń).

W drzewostanie dominuje sosna. Występują tu torfowiska - niskie, przejściowe i wysokie (Kalicka, 2009). Środkowy basen Biebrzy z Czerwonym Bagnem jest odmiennym obszarem w stosunku do basenu południowego. Spotyka się tu znaczne obszary borów bagiennych i turzycowisk wysokich. Najatrakcyjniejszym walorem są wydmy - widok rzadko spotykany w połączeniu z bagnami. Sąsiedztwo bagiennej doliny z piaszczystymi wydmami najlepiej ukazują okolice Wilczej Góry i Tchórzych Grzęd. W obwodzie Grzędy wyznaczono trzy ścieżki dydaktyczne: czarną „Czerwone Bagno”, żółtą „Borek Bartny” i zieloną „Wydmy” oraz pięć szlaków turystycznych: czerwony, zielony, niebieski, czarny i żółty ${ }^{18}$. Wśród ścieżek najwyższą atrakcyjnością przyrodniczą odznaczają się: „Czerwone Bagno”kilometrowej długości kładka przez bór bagienny, na końcu zakończona platformą widokową oraz ścieżka „Wydmy” prowadząca przez, jak wskazuje nazwa, wydmy tych terenów. Najbardziej spektakularne obserwować można poniżej uroczyska Nowy Świat, w okolicach Wilczej Góry. Śródlądowe wydmy są tutaj odsłonięte od lasu; po drugiej stronie przechodzą w obszar bagienny. Na terenie obszaru Grzędy ciekawym elementem krajobrazowym są wydmy leśne. Te, najczęściej porośnięte brzozą lub sosną wzniesienia, najlepiej ukazują góry: Partyczyzna i Barwik, które znajdują się na trasie niebieskiego i czarnego szlaku.

\footnotetext{
${ }^{18}$ http://www.biebrza.org.pl/, data wejścia [01.10.2014 r.]
} 
Najlepszym punktem widokowym na terenie Obszaru Ochronnego Grzędy jest Wilcza Góra (Fot. 6). Zlokalizowana na wydmowym wyniesieniu wieża widokowa ukazuje urozmaicony krajobraz: z jednej strony bagienną dolinę, z drugiej piaszczyste wydmy, by z jeszcze innej przedstawiać las na terenie Czerwonego Bagna.

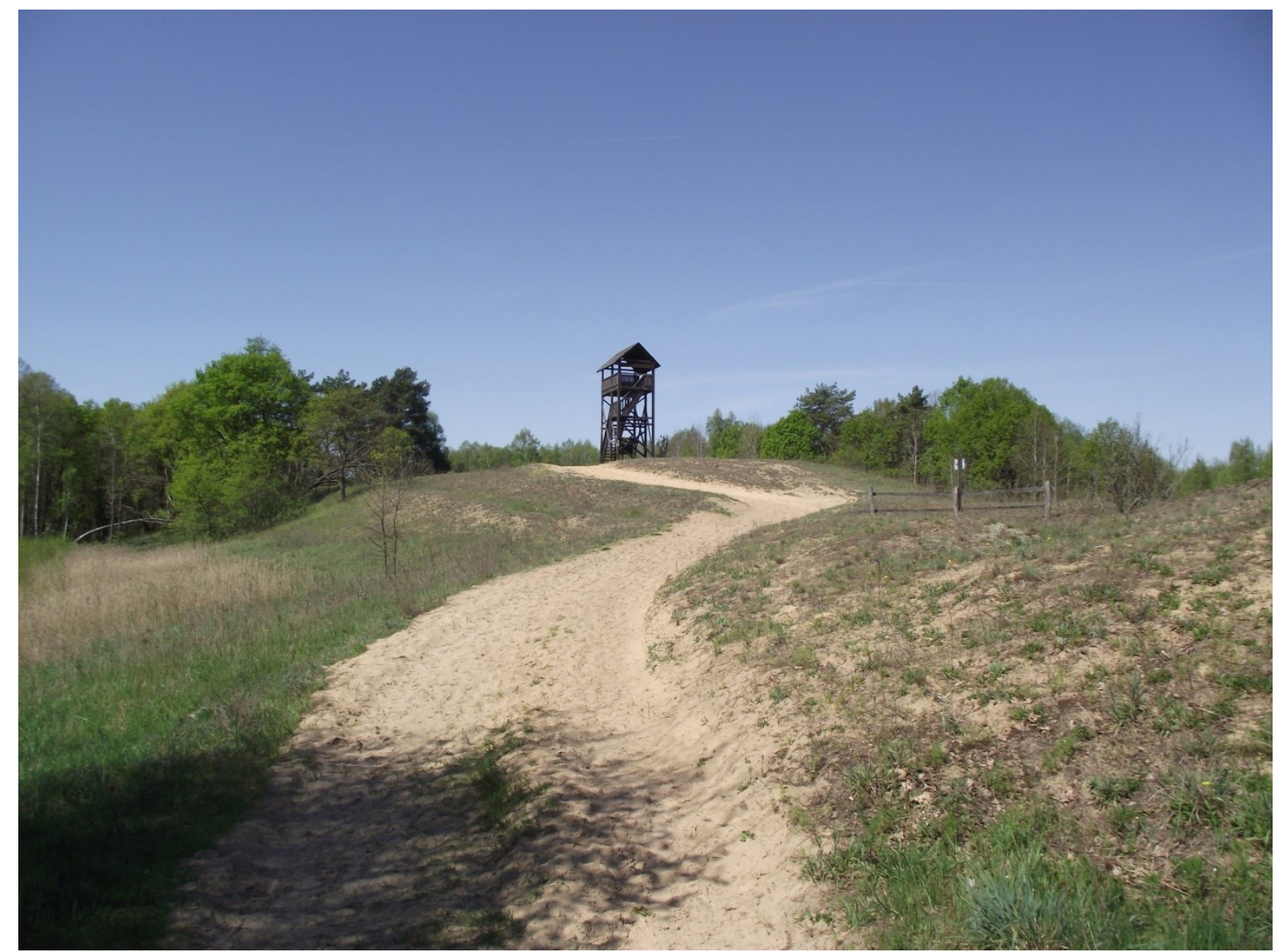

Fot. 6. Wilcza Góra (Fot. Rafał Moroń).

Na terenie Biebrzańskiego Parku Narodowego leży twierdza w Osowcu. Ta wzniesiona pod koniec XIX wieku budowla wojskowa spełniała bardzo ważne strategicznie zadanie była swoistą zaporą przez bagna biebrzańskie, ponieważ w tym miejscu dolina rzeki jest najwęższa. Na twierdzę składały się cztery forty: I centralny, II zarzeczny, III szwedzki i IV nowy. Carska twierdza nie została nigdy zdobyta, przez co porównuje się ją do francuskiego Verdun. Na terenie fortu centralnego mieści się Muzeum Twierdzy Osowiec, ukazujące szczegóły umocnień, maszyny wojenne i sposoby obrony twierdzy (Największe atrakcje...).

Biebrzański Park Narodowy wraz z gminą Trzcianne organizuje Mistrzostwa Polski w koszeniu łąk bagiennych, czyli tzw. „biebrzańskie sianokosy”. Impreza odbywa się na terenie bagna Ławki, a jej celem jest ocalenie wieloletniej tradycji, co przy okazji stanowi czynną ochronę przyrody. W Osowcu-Twierdzy dwukrotnie w roku odbywają się targi wytwórczości i sztuki ludowej „Sto pomysłów dla Biebrzy”, prezentujące lokalne wyroby z Podlasia, Warmii i Mazur czy Mazowsza. Przy okazji imprezy można uczestniczyć w warsztatach tradycyjnych rzemiosł: kowalstwa, garncarstwa czy wypieku sękacza (Największe atrakcje...). Centrum sztuki ludowej $\mathrm{w}$ regionie jest Lipsk $\mathrm{z}$ licznymi pracowniami 
pisankarskimi oraz Muzeum Lipskiej Pisanki ${ }^{19}$. Interesującą imprezą jest turniej nalewek „Biebrzański łyk” promujący domowe, naturalnie pędzone napoje alkoholowe ${ }^{20}$.

Malownicze wypukłości polodowcowego krajobrazu, w połączeniu z obecnością czystych jezior sprawiają, że teren Wigierskiego PN jest regionem niezwykle atrakcyjnym. Liczne wzgórza morenowe są dogodnym punktem widokowym na tutejsze jeziora. Aż $62 \%$ powierzchni parku stanowią lasy (Ambrosiewicz, 2009).

Maksymalna głębokość polodowcowego jeziora Wigry dochodzi do 74 metrów. Dno ma różny charakter, przez co głębokość zbiornika jest zróżnicowana (Krzysztofiak, 2010). Powierzchnia lustra wody wynosi 2118 ha. Linia brzegowa jest kręta i urozmaicona, a jej długość wynosi $72 \mathrm{~km}$. Na jeziorze obecnych jest 15 wysp. Wśród bogatej ichtiofauny na uwagę zasługuje obecność sielawy i siei (Ambrosiewicz, 2009; Kamiński, 2001).

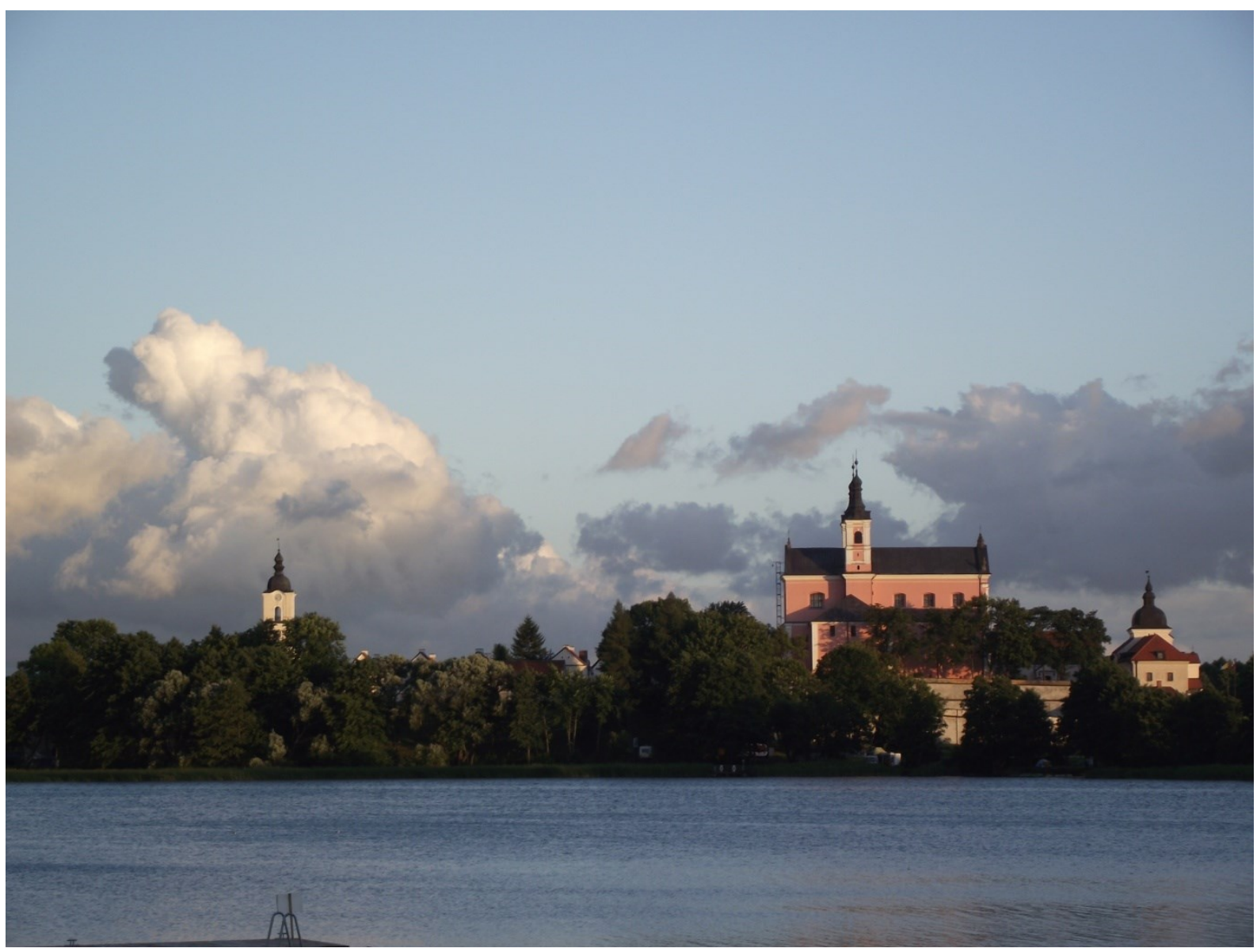

Fot. 7. Pokamedulski zespół klasztorny na tle jeziora wigierskiego (Fot. Rafał Moroń).

Okolone licznymi półwyspami jezioro, z górującym Pokamedulskim Zespołem Klasztornym zaskakuje różnorodnością krajobrazu (Fot. 7). Najlepszymi punktami widokowymi są: wieża zegarowa Pokamedulskiego Zespołu Klasztornego w Wigrach oraz wieża widokowa w okolicach Krusznika. Na terenie parku, prócz głównego jeziora Wigry, znajduje się kilkanaście zbiorników, różniących się kształtem, wielkością, głębokością oraz

\footnotetext{
${ }^{19}$ http://www.wrotapodlasia.pl/, data wejścia [06.01.2014 r.]

${ }^{20}$ http://www.biebrza.org.pl/, data wejścia [06.01.2014 r.]
} 
stopniem żyzności wody. Wśród nich na uwagę zasługują „suchary” (Fot. 8) - śródleśne jeziora o niewielkiej powierzchni i głębokości. Nazwę „suchar” jako pierwszy wprowadził wybitny hydrolog i badacz tych ziem - Alfred Lityński. Uważa się, iż nazwa wzięła się od suchych, obumarłych drzew widocznych przy brzegach tych jezior. „Suchary” są praktycznie bezodpływowe. Brak wymienności wody oraz leśna izolacja od wiatru utrudniają filtrację cieczy. Zbiorniki te są mało żyzne. Zawierają znaczne ilości kwasów humusowych powstałych w wyniku rozkładu ściółki leśnej. Swoją brunatną barwę zawdzięczają owym substancjom. Na terenie parku znajduje się 18 tego typu zbiorników. Największym jest Suchar Wielki - 8, 8 ha, zaś najgłębszym Wądołek - $15 \mathrm{~m}$. Spotyka się tu pływającego pająka topika, wiele larw ważek, muchówek czy chrząszczy (Ambrosiewicz, 2009).

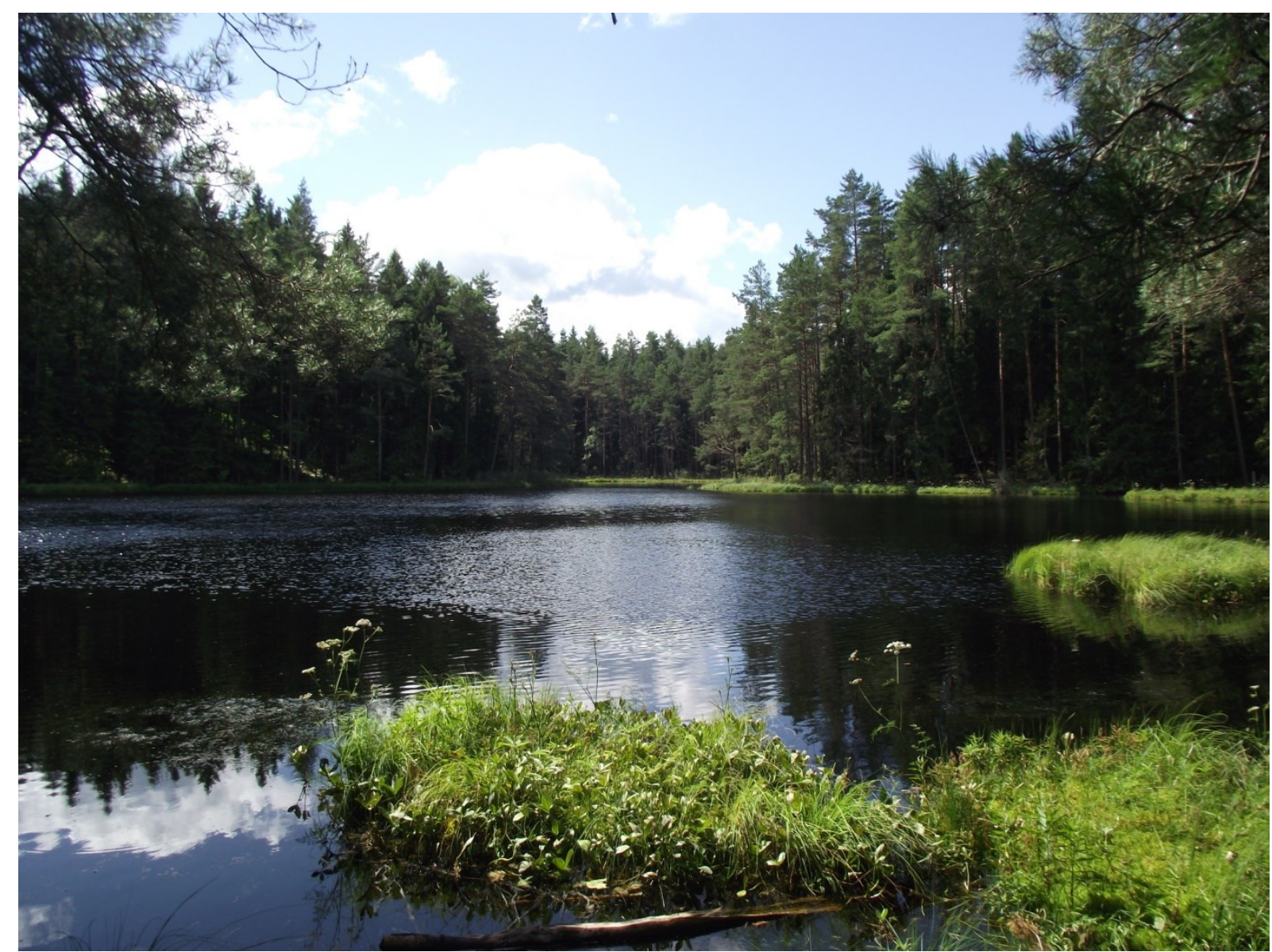

Fot. 8. Jeden z wigierskich „sucharów” w okolicy Krzywego (Fot. Rafał Moroń).

Największą z rzek Wigierskiego PN jest Czarna Hańcza. Ciekawym fragmentem rzeki jest malowniczy i tajemniczy odcinek przed ujściem do jeziora Wigry, gdzie rzeka płynie w otoczeniu bagnistej doliny (Fot. 9). Woda płynie tu wąskim korytem o dość bystrym nurcie. (Ambrosiewicz, 2009).

W Starym Folwarku mieści się nowoczesne, niezwykle atrakcyjne Muzeum Wigier im. Alfreda Lityńskiego. Stała ekspozycja ukazuje ekosystemy lądowe, rzeczne i jeziorne Wigierskiego PN, historię oraz badania dawnej Stacji Hydrobiologicznej, torfowiska, historie 
wigierskiego krajobrazu i historyczną działalność człowieka nadwigierskich ziem ${ }^{21}$. Ekspozycje podzielone są tematycznie - każda w osobnym miejscu - a kolejność zwiedzania dowolna. Obejrzeć tu można pod mikroskopem różnego rodzaju grzyby, film o historii ziemi wigierskiej oraz posłuchać śpiewu wybranych przez siebie okazów ptaków. Bardzo ciekawa jest również wystawa w budynku siedziby dyrekcji parku w Krzywem. Audio-przewodnik wprowadza turystów w ciekawy świat tutejszych zwierząt oraz środowiska, w których żyją.

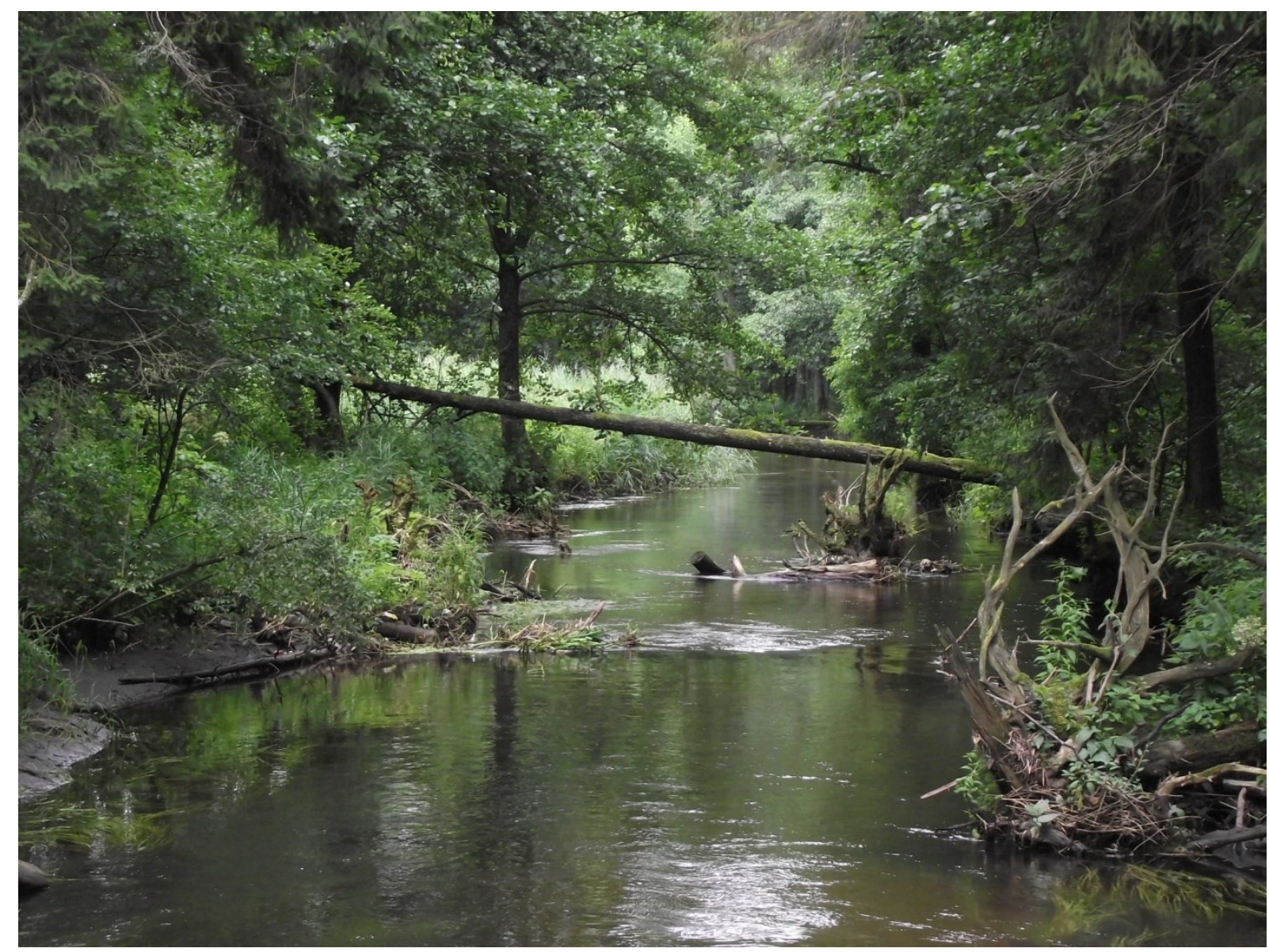

Fot. 9. Dziewicza Dolina Czarnej Hańczy (Fot. Rafał Moroń).

$\mathrm{Na}$ terenie parku narodowego - w Wigrach - znajduje się Pokemdulski Zespół Klasztorny. Historia klasztoru sięga XVII w., kiedy król Jan Kazimierz nadał tutejsze dobra zakonowi kamedułów. Klasztorny kompleks składa się z: barokowego kościoła pw Niepokalanego Poczęcia Najświętszej Marii Panny, wieży zegarowej, domu gościnnego, refektarza, domku furtiana, różnych pomieszczeń gospodarczych oraz siedemnastu eremów ${ }^{22}$. W wigierskim zespole klasztornym znajduje się Muzeum Jana Pawła II, składające się z Apartamentów Papieskich, Kaplicy Papieskiej oraz Biblioteki, które od czasu wizyty Ojca Świętego w czerwcu 1999 r. pozostały niezmienione ${ }^{23}$. Na tyłach kompleksu klasztornego znajduje się ogród z drewnianymi figurami świętych. Interesującym zabytkiem techniki, ale i

\footnotetext{
${ }^{21}$ http://www.wigry.win.pl/, data wejścia [08.05.2014 r.]

${ }^{22}$ http://www.suwalszczyzna.net/, data wejścia [10.01.2014 r.]

${ }^{23}$ http://www.wigry.pro/, data wejścia [10.01.2014 r.]
} 
formą zwiedzania pobliskiej przyrody jest kolejka wąskotorowa, powstała po dawnej kolejce leśnej. Startowy i końcowy przystanek trasy kolejki umiejscowiony jest w Płocicznie, gdzie znajduje się również Muzeum Kolejki ${ }^{24}$.

Utworzony w 1976 roku Suwalski Park Krajobrazowy, jest najstarszym tego typu obszarem chronionym w Polsce. Miejsce charakteryzują otwarte przestrzenie odkrywające przed obserwatorem bogatą rzeźbę tutejszego krajobrazu. Ukształtowany przez zlodowacenie północnopolskie teren, tworzą przede wszystkim wysoczyzny morenowe: Hańczanska, Dzierwan, Gulbieniszk, Krzenianki i Surpił oraz doliny rzeczne: Szeszupy i Czarnej Hańczy.

Niezwykle malownicza jest dolina Czarnej Hańczy. Rzeka bierze swój początek w okolicach wsi Okliny, w otulinie parku. Następnie wpada do jeziora Hańcza, by przejść w wartki potok o wysokim spadku wody. Dolina rzeki jest tutaj wąska, a jej środkiem na 3-kilometrowym odcinku ciągnie się oz [długi, krety, wąski ciąg wzgórz zbudowanych z piasków i żwirów, osadzonych przez wody płynące pod lodowcem] tortulski - najpiękniejszy przykład ozu w kraju. Za Bachanowem rzeka zwalnia tempo, dolina porośnięta łęgiem się rozszerza, a rzeka spokojnie meandruje.

$\mathrm{Na}$ terenie parku znajdują się 24 jeziora. Największym i najgłębszym jest jezioro Hańcza - rynnowe, o genezie polodowcowej. Maksymalna głębokość jeziora dochodzi do 109 m, co sprawia, że jest najgłębsze w Polsce i Europie niżowej.

W parku wyznaczono 4 rezerwaty przyrody: „Jezioro Hańcza”, „Głazowisko Bachanowo nad Czarną Hańczą”, „Głazowisko Łopuchowskie” oraz „Rutka”. Ponadto, znajduje się tu 39 pomników przyrody (22 pojedyncze drzewa, 2 grupy drzew oraz 15 głazów narzutowych). Ciekawą atrakcją parku są głazowiska - Łopuchowskie, Rutka i Bachanowo $\mathrm{z}$ licznymi głazami narzutowymi o różnej wielkości (obwód od 0,5 do $8,0 \mathrm{~m}$.) ${ }^{25}$.

Suwalski PK urzeka różnorodnością pofałdowanego krajobrazu. Najsłynniejszym wzniesieniem w parku jest Góra Cisowa, nazywana również „Suwalską Fudżijamą” czy „Górą Sypaną”. Góra ma wysokość 256 m n.p.m. i jest moreną czołową o regularnym kształcie. Wzniesienie jest doskonałym punktem widokowym, skąd świetnie widać krajobraz zagłębienia Szeszupy.

„Kraina Otwartych Okiennic” to szlak utworzony w ramach projektu Północnopodlaskiego Stowarzyszenia Ochrony Ptaków. Szlak wiedzie przez trzy malownicze wsie: Trześcianka i Puchły (znajdujące się na trasie Bocianiego Szlaku) oraz Soce. Charakterystycznym elementem architektonicznym wsi są bogate, często jaskrawe zdobienia okiennic, narożników czy wiatrownic. Tradycyjną, starodawną ornamentykę budownictwa ludowego kultywuje tu prawosławna ludność pochodzenia białoruskiego. Znajdują się tu również bogato zdobione cerkwie ${ }^{26}$.

Ważnym punktem na opisywanym Bocianim szlaku jest Tykocin. Niecałe 100 lat temu połowę ludności miasta stanowili Żydzi. Większość zginęła w czasie II wojny światowej. Pozostała synagoga - druga pod względem wielkości w kraju - z licznym asortymentem w postaci świeczników szabasowych czy lampek chanukowych. Tykocin często określa się jako perłę polskiego baroku, z uwagi na budowle pochodzące z owego okresu - alumnat, kościół Trójcy Przenajświętszej czy drugi w kraju świecki pomnik - hetmana Stefana Czarnieckiego (Największe atrakcje...).

Kolejna wieś $\mathrm{z}$ bogatą historią i kulturą, Sztabin, położona jest na obrzeżach Biebrzańskiego PN. W pierwszej połowie XIX wieku powstała tu „Rzeczpospolita Sztabińska". Swoistą utopię kapitalistyczną na zasadach spółdzielni rolno-przemysłowej

\footnotetext{
${ }^{24}$ http://www.photopodlasie.com/, data wejścia [16.01.2014 r.]

${ }^{25}$ http://www.spk.org.pl/, data wejścia [15.09.2014 r.]

${ }^{26}$ http://www.ciekawepodlasie.pl/, data wejścia [05.09.2014 r.]
} 
stworzył hrabia Karol Brzostowski. Polski pionier i wizjoner, jako pierwszy w kraju uwłaszczył chłopów. Poprzez przymusową i darmową edukację sprawił, że kilkadziesiąt lat później większość zacofanych dotychczas ludzi potrafiła pisać i czytać. Założył świetnie prosperującą hutę szkła oraz zakład produkcji maszyn rolniczych. Zbudował maszynę parową oraz pierwszą w Polsce sieć telegraficzną, wybudował gorzelnię, młyn wodny, tartak, browar, wytwórnię wódek gatunkowych, cegielnię i wiatrak. Wprowadził także zasiłki dla najbardziej potrzebujących, a w czasach kryzysu głodowego sprzedawał zboże ze zwielokrotnioną zniżką. „Rzeczpospolita Sztabińska” istniała 35 lat, będąc jednym z najprężniej działających i najbardziej wydajnych ośrodków przemysłowych w kraju. Pamięć o hrabim Karolu pozostała. We wsi stoi pomnik ,rewolucyjnego” pioniera, a tutejsi mieszkańcy nie zapomnieli o swoim dawnym patronie ${ }^{27}$.

Bociani Szlak kończy się w Stańczykach - wsi na pograniczu województw podlaskiego i warmińsko-mazurskiego, położonej malowniczo nad rzeką Błędzianką. Najsłynniejszą atrakcją są tu ,polskie akwedukty”, jak nazywa się mosty w Stańczykach. Mosty kolejowe wybudowano tu na początku XX wieku. Jako pierwszy powstał most północny. Powstały ponad 10 lat później most południowy, miał pełnić rolę tarasu widokowego oraz mostu rezerwowego, na wypadek zbombardowania głównego przęsła kolejowego. Mosty łączą brzegi pradoliny Błędzianki i mają długość 180 metrów $^{28}$.

\section{2. Dolina Biebrzy - mekka birdwatcherów}

Forma turystyki, wchodząca w skład szerzej pojmowanej ekoturystyki, polegająca na obserwacji ptaków nosi z ang. nazwę birdwatchingu. Obserwowanie ptaków nazywa się również birdingiem (nie tylko podglądanie, ale i ich słuchanie) oraz twichingiem (wyszukiwanie rzadkich gatunków). Birdawtching staje się w Polsce coraz bardziej popularny $\mathrm{z}$ uwagi na $\mathrm{w}$ miarę tani $\mathrm{i}$ latwo dostępny sprzęt (lornetki, kamery video, aparaty fotograficzne), powszechne opracowania ornitologiczne oraz ilość ptaków i mnogość terenów do ich obserwacji. Szacuje się, iż liczba obserwatorów w Polsce (zarówno tych krajowych, jak i przyjezdnych) wynosi kilka tysięcy rocznie. Do uprawiania tego typu turystyki aktywnej przyznaje się około 3 tys. Polaków. Obserwacja ptaków wymaga od turystów przygotowania pod względem sprzętu, jak i znajomości poszczególnych gatunków. Jest atrakcyjną formą spędzania wolnego czasu, a ponieważ zapewnia bezinwazyjny kontakt z przyrodą, wpisuje się też w definicję ekoturystyki (Janeczko i Anderwald, 2011; Gołoś, 2012). Ptactwo na terenach niezurbanizowanych często bywa płochliwe, dlatego ważna jest odpowiednia infrastruktura umożliwiająca obserwację i fotografowanie $\mathrm{z}$ odpowiednio przystosowanych do tego miejsc. Wiele takich miejsc znajduje się w Biebrzańskim PN, który szczególnie w maju roi się od wielbicieli ptaków. Bagna Podlaskie i Ławki są jednymi z największych kompleksów w Europie - obserwatorzy z całego kraju i Europy „nawiedzają” Dolinę Biebrzy, aby móc obejrzeć ptaki takie jak: bataliony, wodniczki czy cietrzewie.

\section{PODSUMOWANIE}

W dobie postępującej technologizacji, ekoturystyka staje się jedną z alternatyw dla monotonnej i szkodzącej naturze oraz kulturze turystyki masowej. Dzięki coraz większemu poziomowi świadomości ekologicznej, turyści częściej wybierają przyjazny dla środowiska i

\footnotetext{
${ }^{27}$ http://www.uwazamrze.pl/, data wejścia [15.09.2014 r.]

${ }^{28} \mathrm{http}: / /$ www.suwalszczyzna.com.pl/, data wejścia [15.09.2014 r.]
} 
lokalnych społeczności rodzaj turystyki. W dalszym ciągu, jest to jednak forma niszowa. Patrząc realnie na prognozy dotyczące światowych trendów w turystyce, zauważalny jest $\mathrm{w}$ ostatnich latach fakt większego zainteresowania turystyką ekologiczną. Wiązać się to może z coraz szybszym tempem życia w krajach cywilizowanych, w których ludzie chcą niejako „wrócić do korzeni”, a więc kooegzystować z przyrodą i lokalną kulturą zamiast je degradować i wykorzystywać.

Podlasie jest obszarem o wybitnych walorach przyrodniczych i kulturowych. Odpowiednie wykorzystanie zasobów turystycznych może poprawić sytuację ekonomiczną lokalnej społeczności oraz chronić zanikające już powoli ludowe tradycje. Niski stopień zagospodarowania obszaru pozytywnie działa na miejscową przyrodę. Ekoturystyczny potencjał Podlasia jest olbrzymi. Markowy produkt turystyczny - Podlaski Szlak Bociani rokrocznie wpływać może na wykorzystanie owego potencjału, z obopólną korzyścią dla regionu i turystów. Obecność czterech parków narodowych oraz jednego krajobrazowego, jako obszarów o wybitnych walorach przyrodniczych, podnosi atrakcyjność opisywanego szlaku. W połączeniu z wartościami lokalnej kultury ludowej, szlak idealnie wpasowuje się do pojęcia produktu ekoturystycznego.

Każdy z obszarów chronionych znajdujących się na szlaku, poszczycić się może innymi walorami. Białowieski PN to przede wszystkim pierwotne lasy Puszczy Białowieskiej oraz największy europejski ssak - żubr. Narwiański PN to anastomozujący system rzeki Narwi. Biebrzański to niezmierzone połacie bagiennego krajobrazu. Wigierski zaś to czyste wody jeziora wigierskiego z górującym ponad nimi Pokemedulskim Zespołem Klasztornym. „Garbata” kraina z ,polską Fudżijamą”, czyli Górą Cisową oraz najgłębszym polskim jeziorem - Hańczą to wizytówki Suwalskiego PK. Dolina Biebrzy, znajdująca się na trasie Podlaskiego Szlaku Bocianiego, jest jednym $\mathrm{z}$ najatrakcyjniejszych miejsc dla birdwatcherów. Turystyka ornitologiczna, jako jeden z rodzajów szerzej pojętej ekoturystyki, staje się coraz popularniejsza. Najazd ,"ptasich turystów”, przypada przede wszystkim (ale nie tylko) na majowy okres godowy skrzydlatych zwierząt.

$\mathrm{Na}$ zakończenie warto podkreślić edukacyjne walory jakie niesie za sobą ekoturystyka. Podlasie jest doskonałym miejscem na szkolne wycieczki, bowiem w tym rejonie krzyżują się źródła wielu informacji historycznych, przyrodniczych czy geograficznych, które w połączeniu z edukacyjnym charakterem obszarów chronionych pozwalają na przeprowadzenie wielu ciekawych lekcji w ,terenie” zarówno dla młodszych grup wiekowych, jak i młodzieży gimnazjalnej i licealnej.

\section{References}

[1] M. Ambrosiewicz, Wydawnictwo Wigierski Park Narodowy, Krzywe (2009).

[2] M. Barwiński, Wydawnictwo Uniwersytetu Łódzkiego, Łódź (2004).

[3] Biebrzańskie szlaki. Ścieżki edukacyjne: „, Grobla Honczarowska”, „,Barwik”, Dluga Luka”, praca zbiorowa, Wydawnictwo Biebrzański Park Narodowy, Osowiec-Twierdza (2006).

[4] M. Durydiwka, P. Kociszewski, Turystyka Kulturowa 6 (2013) 5-29.

[5] G. Gołoś, Rynek Turystyczny, 2/317 (2012) 40-41.

[6] R. Gradziński, Wydawnictwo Narwiański Park Narodowy, Kurowo (2004).

[7] E. Janeczko, D. Anderwald, Studia i Materiaty CEPL w Rogowie, 2/27 (2011). 
[8] E. Kalicka, Oficyna wydawnicza FOREST, Józefów (2009).

[9] M. Kamiński, Wigry 2 (2001).

[10] L. Krzysztofiak, Wigry 1 (2010).

[11] Największe atrakcje turystyczne w województwie podlaskim PDF, Białystok (2010).

[12] B.E. Wysmułek, Wydawnictwo Ekonomia i Środowisko, Białystok (1994).

[13] D. Zaręba, $P W N$, Warszawa (2006).

[14] http://www.atrakcjepodlasia.pl/

[15] http://www.bialystok.pl/

[16] http://www.bialystokonline.pl/

[17] http://www.bialowieza.pl/

[18] http://www.bialowieza-info.eu/

[19] http://www.biebrza.org.pl/

[20] http://bpn.com.pl/

[21] http://www.ciekawepodlasie.pl/

[22] http://dziedzictwo.ekai.pl/

[23] http://www.greenways.pl/pl/

[24] http://www.npn.pl/

[25] http://www.minrol.gov.pl/

[26] http://www.photopodlasie.com/

[27] http://www.podlaskiszlakbociani.pl/,

[28] http://www.spk.org.pl

[29] http://www.stat.gov.pl/

[30] http://www.suwalszczyzna.com.pl/

[31] http://www.suwalszczyzna.net/

[32] http://www.uwazamrze.pl/,

[33] http://www.wigry.win.pl/

[34] http://www.wigry.pro/

[35] http://www.wrotapodlasia.pl/ 